\title{
O-46 原発性湭睄移行上皮密の臨床的検討
}

兵庫医科大学

森 義則, 島 博基, 井原英有, 薮元秀典, 小池 宏, 藤末 洋, 野島道生, 生駒文彦

（目的）兵庫医科大学において経験した原発性移行上皮疸症例の治療とその結果について検討する。 （対象と方法）1978年から1993年までに治寮した13例で，男性12例，女性1例。年跉は41藏から76歳 (平均65.2歳)。2例は職業性膀胱痹であった。症状は頻尿，排㽷痛のような膀胱刺激症状がほとんどで， 1例のみが血尿であった。尿細胞診は全例陽性で, 最初の生検でCISを認めたのは8例で, dysplasiaか denuding cystitisのものが5例であったが,これらはいずれも経過観察中に後になって移行上皮疸が認め られた。初回治療はBCG膀胱内注入5例，Adriamycin膀胱内注入4例および膀胱全摘術4例であった。

(結果) BCG膀注症例は1例が追跡不能で, 残り4例のうち2例は2年と7年後に浸潤性膀胼癌が発生し膀 脱全摘除術が施行された。残りの2例は再発なく経過している。Adriamycin膀注症例のうち1例は追跡 不能で，残り3例はいずれも6か月，8か月および3年後に浸潤癌が発生し膀胱全摘を施行し，そのうち1 例は8年後に笃孟癌のため死しした。膀注症例で浸潤癌を発生したもののうち，2例は膀胱筋層へ，2例 は前立腺間質へ，1例はその両者へ浸潤が生じた。最初から膀胱全摘除術を施行した4例の内2例は胃肉 腫と胃嗝のため各々 2 年と 8 年後に死亡したが, 残り2例は5年と 9 年間再発なく生存している。全症例の 実測生存率は，3年77.8\%，5年65.8\%，10年 $22.0 \%$ あった。

(結論) BCGや抗ガン剂の膀胱内注入寮法は最初は有効であっても長期間の経過観察中に癌が再発・進 展することがあり，そのさい膀胱筋層への浸閵のみならず, 前立腺への進展も重要である。膀胱全摘 除術を施行する時期を失しないように注意が必要である。

$0-47$

表在性膀脱病に対する塩酸エピルビシン術後再発予防早期注入療法の検时

関東学災病院

有贺誠司、山崎哲、栗本重陽、小松秀樹、石田仁男

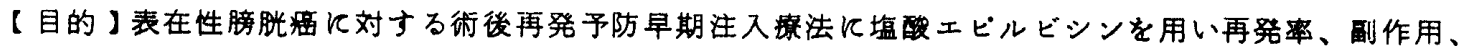

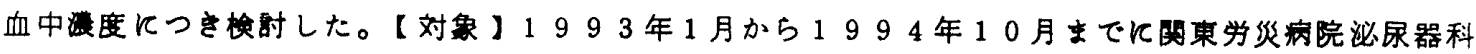

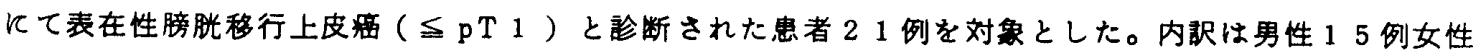
6 例、42才 84才（平均 60 才）、初発 17 例、再発 4 例、単発 10 例、多発 11 例、組織学的悪 性度はG1 8 例、G2 12 例、G3 1 例であった。【方法】塩酸エピルビシン $40 \mathrm{mg}$ 生食 $40 \mathrm{mer}$ 溶解し、TUR-B t 直後、2 病日、5病日、8病日、1 1 病日の計 5 回膀胱内飞注入した。莱剂は膀胱 内に 2 時間把持することとした。 5 例では術直後での膀脱内注入前後の塩酸エビルビシンの血中灌度を

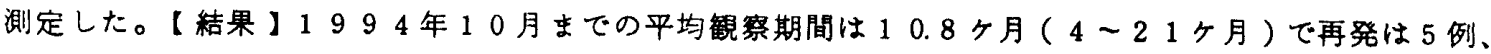
$23.8 \%$ (初発 3 例、再発 2 例)ですべて多発例であった。副作用として頻尿、残尿感などの膀脱刺激 症状が 4 例（19\%）にみられ、5ち2例では投与を中断した。血中浱度は投与後 30 分から1時間に

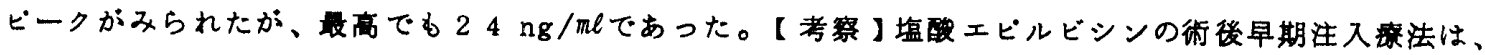
初発例と単発例では高い再発予防奻果が認められ、また副作用の出現頻度中血中漊度の上年は心配され るほどのものではなく、再発予防に極めて有用な方法であると思われた。 